\title{
Possible Supernumerary Chromosome Associated with Hypodontia
}

\author{
CARLOS E. NASJLETI, JAMES HARRIS, JAMES M. WALDEN, \\ and JOSEPH T. HARTSOOK \\ Dental Research Section, Veterans Administration Hospital, and \\ University of Michigan School of Dentistry, Ann Arbor, Michigan
}

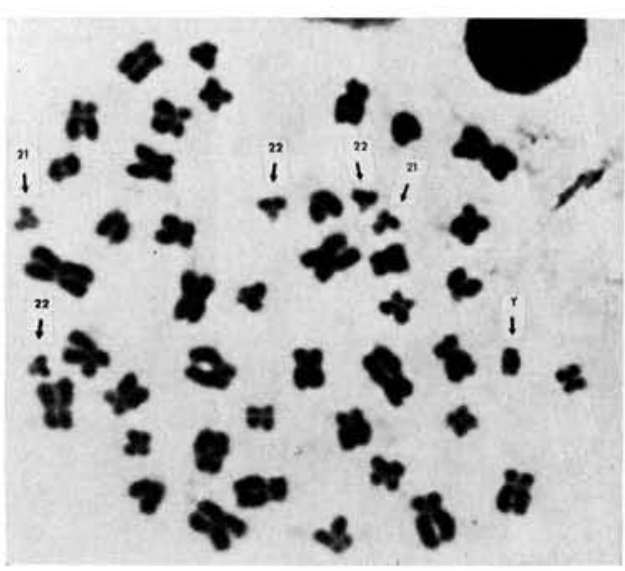

FIG. 1.-Male cell metaphase with six small acrocentric chromosomes (arrows) instead of five.

Thosen (Amer. J. phys. Anthrop., [n.s.] 10:155, 1952) listed dominant, irregular dominant, recessive, and sex-linked genes as the explanation for hypodontia. Grahnén (Odont. Revy, 7, Suppl. 3, 1956) concluded from studies of Swedish families that dominant genes were involved in the majority of cases of hypodontia and that probably a number of genetic entities were associated with its occurrence. Evidence exists for genetic origin in the etiology of hypodontia; however, the mode of transmission is still unsolved.

During a survey for chromosome anomalies in oral congenital diseases, a definite abnormality was observed in the karyotype of cells analyzed in an 11-year-old boy with hypodontia. On oral examination, he demonstrated multiple caries in primary and permanent teeth, anterior crowding, and gingivitis. The mandibular right second bicuspid was missing clinically and radiographically. Physical examination revealed a heart murmur and deafness in one ear. His medical history disclosed scarlet fever at age 3 and a tonsillectomy at 8 years of age. His four sisters and one brother were healthy and had no record of missing teeth. Cbromosome preparations, using the method of P. S. Moorhead and others

Additional information is available on request to the authors.

Received for publication February 4, 1965.
(Exp. Cell Res., 20:613-16, 1960), showed a mosaic of two cell populations, one with 46 and the other with 47 chromosomes.

In chromosome analysis of 100 metaphases from the patient, 33 cells showed the supernumerary chromosome (Fig. 1), which was identified by appearance and arm measurement as being similar to No. 22 (Fig. 2), of the Denver Study Group nomenclature (Lancet, 1:1063, 1960). The remaining 67 cells had a normal chromosome complement. Identical results were seen in a second culture.

The occurrence of an extra chromosome and hypodontia may be due to chance, however, so the possibility that these two events are not independent should be explored. Hence, this case of autosomal mosaicism for chromosome 22 is interesting and provocative. It would not be inconsistent then, with the clinical variations observed in hypodontia, to postulate that 1 gene locus, several gene loci, or a supernumerary trisomic chromosome with many gene loci may represent an acceptable genetic model. The chromosomal anomaly probably was the result of mitotic nondisjunction after fertilization, as evidenced by the fact that only one third of the total cells analyzed contained the extra chromosome.

Further investigations in this patient, as well as chromosome analyses of the other members of the family, are in progress.

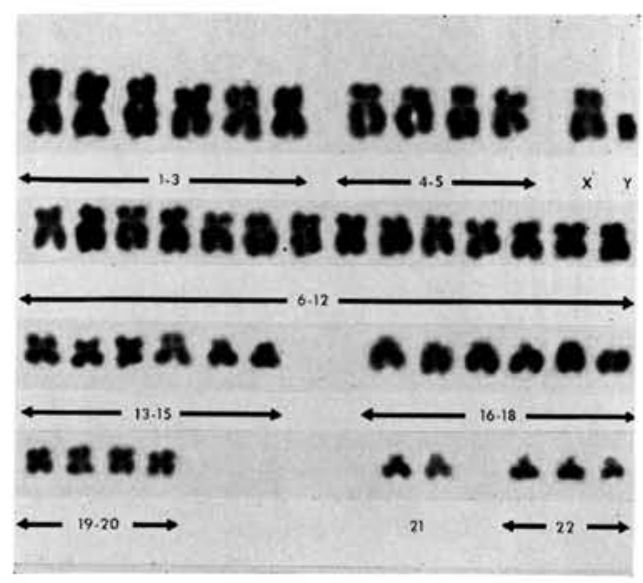

FIG. 2.-Karyotype of cell metaphase shown in Figure 1. 